\title{
Activated eggs offer route to stem cells
}

A technique that could sidestep many of the limitations and ethical concerns that plague the production of human embryonic stem cells was unveiled late last month by a team of US and Russian researchers. The group managed to derive embryonic stem cells from an unfertilized egg - avoiding the need to use viable embryos.

"This is one of the papers we've been waiting for," says George Daley, a stem-cell expert at the Children's Hospital in Boston, Massachusetts, who was not part of the collaboration. But he and others caution that more work needs to be done before the method can be tried in the clinic. And the technique's dependence on access to fresh, unfertilized eggs - a controversial resource — is also likely to limit its application.

The team, led by Elena Revazova and Jeffrey Janus of Lifeline Cell Technology, a biotechnology company in Walkersville, Maryland, created embryos by activating an unfertilized egg using chemicals rather than fertilizing it with sperm (E. S. Revazova et al. Cloning Stem Cells 9, doi:10.1089/clo.2007.0033;2007). Some lizards, birds and insects can reproduce

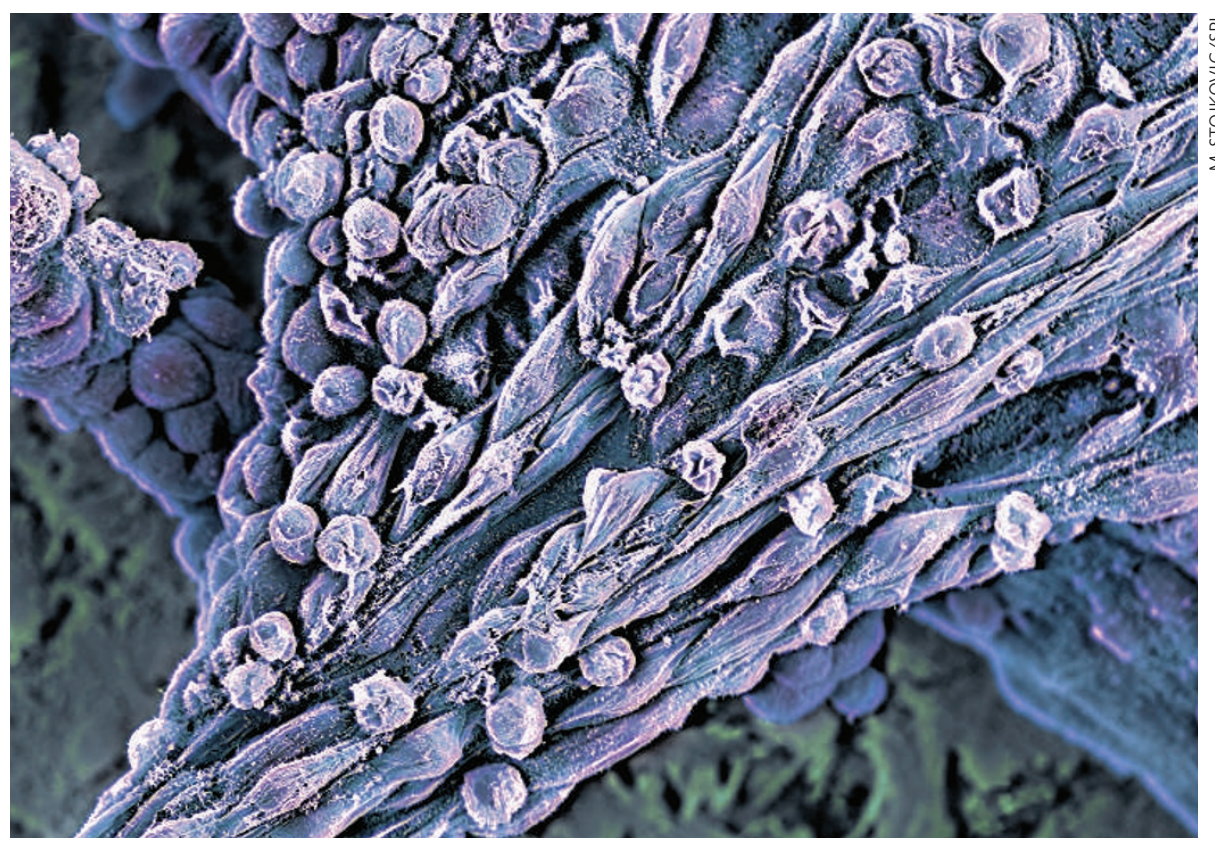

Who's the daddy? Parthenogenesis could provide a more acceptable way to derive embryonic stem cells. without the need for a male - a process known as parthenogenesis - but mammalian parthenotes cannot develop past an early-stage embryo. Revazova and her team managed to get the embryos to develop far enough for them to yield stem cells.

The resulting cells express the same proteins as normal embryonic stem cells and proliferate for an extended period of at least 10 months, the team says. The cells also seem capable of developing into the three primary tissue types. "For all intents and purposes, they are the same" as regular embryonic stem cells, Janus says.

He hopes that the technique will help solve one of the problems associated with stem cells derived from embryos left over from in vitro fertilization (IVF) procedures. Stem cells derived from IVF embryos would not be genetically matched to patients and so if used to treat them would probably provoke an immune response. But, says Janus,

for women, of course, although they might be a good enough immunological match to work for relatives of the donor women too. An alternative approach might be to create a bank of parthenogenetic cells that represent all the immunological 'families' - although estimates for the number of cell lines this would require range from 50 to 1,000 .

Revazova and her colleagues next plan to make cells that could treat liver disease, diabetes and the eye condition macular degeneration. But there are potential problems. Cells express genes differently depending on the parent who provided them. So the next step is to see whether the parthenogenetic cells behave the same as normal cells once they have been turned into a specific tissue type, says Jose Cibelli, a stemcell researcher at Michigan State University in East Lansing.

Daley notes that there have been problems in mice. When parthenogenetic cells were mixed with stem cells from the parthenogenetic embryos should be compatible with the donor's immune system. He admits, however, that "this will have to be proven in a clinical trial".

Daley has already done a proof-of-principle study in mice, in which he transplanted parthenogenetic embryonic stem cells back into the mice without provoking an immune reaction (K. Kim et al. Science 315, 482-486; 2007).

But the cells would be a direct match only
The researchers are optimistic about the efficiency of their technique, saying that they established 6 cell lines using 46 eggs from 5 women. "I am convinced the work can be repeated," says Cibelli.

Use of the technology will be limited by its source: women who bear healthy eggs. The ethics of getting eggs will also be a problem. Janus says the team recruited donors in Russia from women who were undergoing IVF procedures. The team's paper says no financial payment was made to the donors, but Janus says they did cover some costs of the IVF treatment.

Last year, a team at the University of Milan in Italy claimed to have produced parthenogenetic embryonic stem cells, but their results have yet to be published (see Nature 441, 1038; 2006). And significant steps were recently made for another promising method of producing patient-specific cells using genes inserted into mouse skin cells to reprogramme them to an embryonic state (see Nature 447, 618-619; 2007).

The method that would give cells that are the best match for the patient - cloning — has so far failed. With more than 2,000 eggs, South Korea's Woo Suk Hwang failed to produce a single cloned cell line. Ironically, he produced parthenogenetic stem cells - but his team failed to recognize them as such and carried out none of the analyses that could have won the group kudos for the achievement.

David Cyranoski 